TEACHER'S WRITTEN FEEDBACK IN WRITING FOR GRADE 10 STUDENTS OF SENIOR HIGH SCHOOL

\begin{abstract}
AN ARTICLE
Submitted in Partial Fulfillment of the Requirements for the Degree of Sarjana Pendidikan
\end{abstract}

By:

Mouna Fitriana

Registration Number: 2132121061

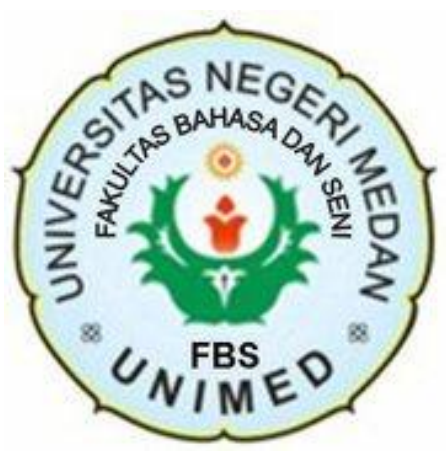

ENGLISH AND LITERATURE DEPARTMENT

FACULTY OF LANGUAGES AND ARTS

STATE UNIVERSITY OF MEDAN

2018 


\section{ARTIKEL}

Disusun dan Diajukan oleh:

Mouna Fitriana

NIM. 2132121061

Telah diverifikasi dan dinyatakan memenuhi syarat untuk diunggah pada jurnal online

Medan, Maret 2018

Menyetujui

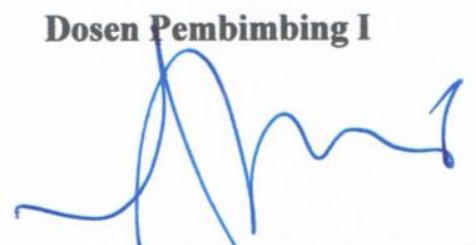

Dr. Anni Holila Pulungan, M.Hum. NIP. 19700522 2001122001
Dosen Pembimbing II

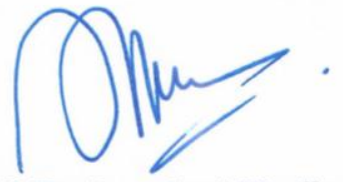

Juli Rachmadani Hasibuan, S.S., M.Hum NIP. 198207112008012008

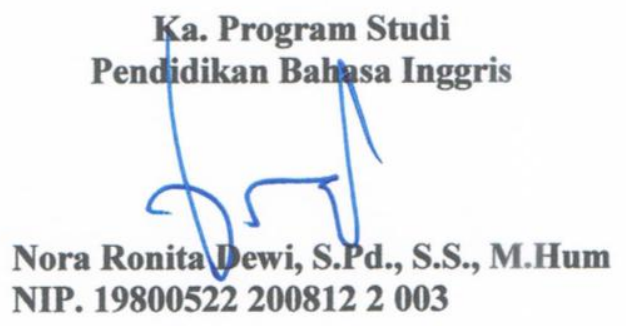




\title{
TEACHER'S WRITTEN FEEDBACK IN WRITING FOR GRADE 10 STUDENTS OF SENIOR HIGH SCHOOL
}

\author{
*Mouna Fitriana \\ **Anni Holila Pulungan \\ **Juli Rachmadani Hasibuan
}

\begin{abstract}
This study were aimed to find out the types of teachers' written feedback in writing which given by the teachers for grade 10, to find out the reason why teacher used those types of written feedbacks on students' writing and also to find out the students' response to the teacher's written feedbacks on students' writing of grade 10 students in SMA YAPIM Taruna Sei Rotan. This research used descriptive qualitative method and the data were collected through documentation and interview. The data collected were analyzed qualitatively. The findings found that there were two types of feedbacks namely, direct written feedback and indirect written feedback. There were 59 direct feedbacks $(52 \%)$ out of 114 total feedbacks. Meanwhile, indirect feedback with 55 un-coded direct feedbacks (48\%) and in this case, teacher did not use coded indirect feedback because the teacher did not understand about the codes. The reason why teacher used those kinds of written feedback on students' writing was because it could make the students have more vocabularies. In conclusion, teacher's written feedbacks were
\end{abstract}


important to made students aware of making mistake on their writing and the students knew about their mistake easily and their writing will be better because they learn from the mistakes. In this case, most of the students felt happy when their teacher gave a correction on their writing. The students said that direct feedback was more effective than indirect feedback because they felt confuse about what the correct word is. By using the direct feedback, the students can have more vocabularies on their next writing. The findings suggested that English teachers was expected to provide a clear description of feedback on writing, especially how students perceive and interpret the feedback given.

Key words: Feedback, Teacher's Written Feedback, Students' Writing

\footnotetext{
*Graduate Status

**Lecturer Status
}

\section{INTRODUCTION}

\section{Background of the Study}

Writing was one of language skill which students can express their ideas in written form. Writing was one of important way to convey information, as Jonah (2006:29) argued that writing can be used as an indirect means of communication to others to convey information. From the definition above, it can be concluded that the purpose of writing was to convey the information from the writers to the readers, to persuade the readers from something that they have read and also to entertain the readers. 
In writing, there were many kinds of genre. Pardiyono (2007:2) divided genre into some kinds, they were Description, Narration, Recount, News Item, Exposition, Discussion, and Procedure text, Report text, and Review. Recount Text was text function as for telling an incident in the past. Recount was to tell "what happened". In senior high school, students learned about recount text. Students in senior high school sometimes think it was so difficult to write what was in their mind because of their limited vocabulary and they have to develop their idea based on their own knowledge and also they have to know about how to arrange their idea into a good sentence to make the readers understand about what they have wrote. Another fact, students miss some grammatical rules in writing, such as they miss spelling in making sentences, they do not know about the tenses they used and they sometimes confused about what will they wrote.

Based on the facts, it showed that the teaching learning of English in classroom has not achieved the goals yet. Many students face the problems in writing. They needed activities which attract them to write. Thorsteinsen (2010: 3) states that feedback is a response given by teacher in the process of learning, it can be written and spoken. Feedback can be positive effect when the students learn from the teacher's feedback. Teacher giving feedback to their students' mistakes was to help the students improve their writing and speaking skills.

Feedback was a process that can help students in their learning process. It can be oral feedback and written feedback. In senior high school, sometimes the teacher did not give any feedback on their students' writing. The reason was because the teacher thought that by giving feedback, it will take more time to check the students' writing. In this case, teacher have to check more than 15 
works of students' writing and it can spend hours to check all of them, even though the teacher can use that time to do other work. The other reason was the teacher was too lazy to check their students' writing because they think it will not make many changes to the students.

In the other case, other teacher expected that by giving feedback, it can make their students can revise their writing to the better one. In fact, some students with high proficiency can understand precisely, but other students with low proficiency can be difficult to understand about their teacher's feedback. Because of the reality, teacher have to know about the students' proficiency to make them know about the feedback. If the teacher did not give any feedback to the students' mistakes, it made the students difficult to their writing later. If the teacher giving corrected the mistakes in the students' writing, it will help the students know about what was wrong and they can learn from their mistakes.

\section{LITERATURE REVIEW}

Writing is one of the productive skills which is dealing with the production of written language. This skill is important to be learnt. Brown (2001: 335) defines writing as the nature of composing process of writing. Jonah (2006:29) argues that writing is a series of activities going on and involve several phases . Both theories had the same ideas, the learners should composing their ideas through the process of thinking, drafting and also revising. Both theories had the same ideas, the learners should composing their ideas through the process of thinking, drafting and also revising. 
Knapp (2005: 224) states that recount text, basically it is written out to make a report about an experience of a series of related event. A recount is written out to inform an event or to entertain people. Recount Text is text function asfor telling an incident in the past. Recount is to tell "what happened". A recount text has a social function. The purpose of a social function is to retell an event with a purpose to inform or entertain the readers (Siahaan and Shinoda, 2008: 9). Recount tells a series of events and evaluate their significance in some way.

Feedback is a process that can help students in learning process. Kauchack and Eggen (1989: 85) define that is any information about current behavior that can be used to improve the future perfomance of the students. Giving feedback is one of the important methods in helping the students improve their writing. Hendrikson (1979: 05) states the erorrs should be corrected because when students read over their written work, they generally are unable to identify many of their errors. It is important for the teacher giving their feedback to students' written work because by giving feedback, it can make a positive effect on students' writing.

Harmer (2007: 147) states that there are two types for giving written feedbacks. They are direct feedback and indirect feedback. Ferris (2002) states that direct feedback refers to teacher providing correct linguistic form for student. Direct feedback takes different forms; it may be done by striking out an incorrectword; inserting a missing word, phrase, or morpheme; and providing the correct linguistic form usually above the wrong form or in the margin (Ferris: 2006). Indirect feedback is a feedback strategy that indicates the existence of an error without providing the correct form (Ferris \& Roberts: 2001). In this type, 
teachers only provide indications that make students aware about their errors but they do not provide the students with the correction. For example, teachers can provide general clues about the location and type of an error by using a line, a circle, a code, a mark, a highlight or a cursor to show omissions in learner's text by placing a cross in the margin next to the line including the error.

\section{RESEARCH METHODOLOGY}

This research was conducted based on the qualitative method. Qualitative research is the understanding of social phenomena from the perspective of human participants (Ary, et al., 2004: 24).

The data of this research was related to kinds of written feedbacks that the teacher gave to fifteen students' writing task and the reason of teacher using those kinds of feedback and also the students' response to the teacher's written feedback.

The sources of this data were the teacher and the grade 10 students of SMA Swasta YAPIM TARUNA Sei Rotan. It was located at Jalan Medan - Batang Kuis Dusun VIII, Sei Rotan, Kec. Percut Sei Tuan Kab. Deli Serdang. The reason for choosing this school as the subject was because the teacher in there was not too concerned with giving feedback.

There were some procedures to get the data which can be selected. But in this case, the researcher selected two procedures to get the data. They were: documentation and interview.

After collecting all the data, the data were analyzed by using qualitative method. The data can be explored from students' writing. Then, the data can be 
classified into : direct written fedback and indirect written feedback. The classification of the feedback was stated by Harmer (2007): there were; direct feedback and indirect feedback. The results of interviews were analyzed by using analytical method proposed by Miles and Huberman (2014).

\section{RESEARCH FINDING AND DISCUSSION}

\section{Research Findings}

The Types of Teacher's Written Feedback that given by the Teacher for

\section{Grade 10}

Harmer (2007: 147) states that there were two types of written feedback. They were direct feedback and indirect feedback. The result of teacher's written feedback based on the students' writing could be seen in the table below.

Table 4.1 The Findings of the Category of Teacher's Written Feedback

$\begin{array}{lllll}\text { Category of } & \text { Written } & \text { Frequency } & \text { Percentage }\end{array}$

Feedback

Direct Feedback

59

52

Indirect Feedback (Coded)

Indirect Feedback (Un-coded) 55

48

The table above showed that direct feedback was the kind of written feedback mostly used by the teacher in correcting students' writing. It counted from 15 
students' writings, there were 59 direct feedbacks (52\%) out of 114 total feedbacks. The teacher also used indirect feedback with 55 un-coded direct feedbacks $(48 \%)$ and in this case, teacher did not use coded indirect feedback because the teacher did not know about the codes. From the table above, it can be concluded that the teacher mostly used direct feedback. The teacher used direct feedback because it can make the students more understand about their correction. So, on the next writing, they will make it better because their teacher gave them the right words on their wrong words. The student's mostly felt happy when they accepted the feedback from the teacher. The student's preferred direct feedback because they did not think about the correct word, it was because their teacher wrote the correct words on their mistake.

From the table above, the percentage of teacher's written feedback on students' writing was revealed in the following figure:

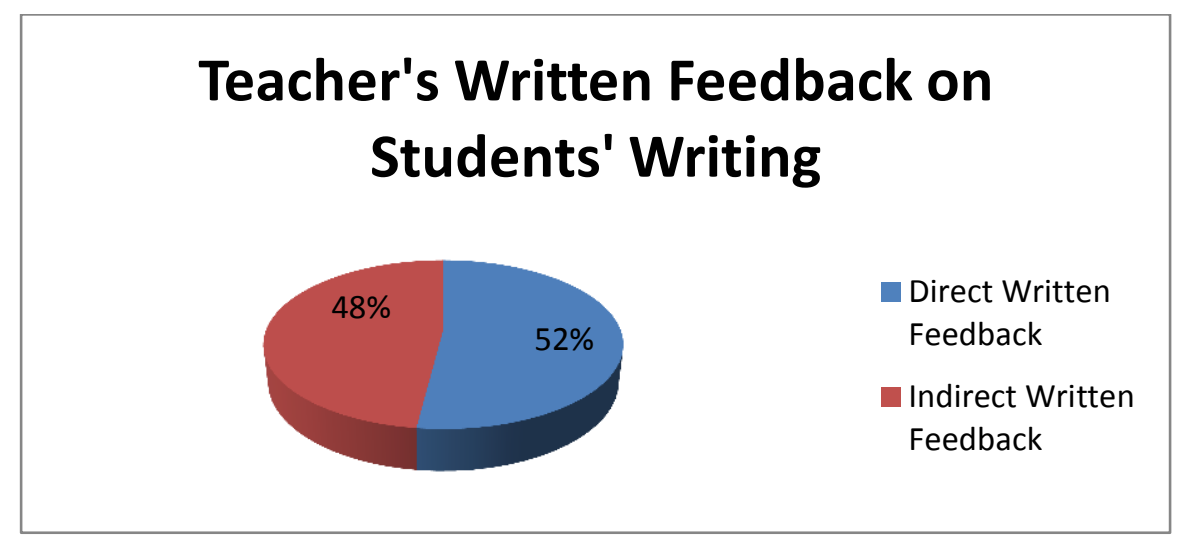

Figure 4.1 The Percentage of Types of Teacher's Written Feedback

The diagram above showed that direct feedback was the kind of written feedback mostly used by the teacher in correcting students' writing. It counted from 15 students' writing, there were 59 direct feedback (52\%) out of 114 total feedback. The teacher also used indirect feedback with 55 un-coded direct 
feedback (48\%) and in this case, teacher did not use coded indirect feedback because the teacher did not know about the codes. From the figure above, it can be concluded that the teacher mostly used direct feedback. The teacher used direct feedback because it can make the students more understand about their mistake. In this case, the teacher gave them the right word on their wrong word. Because of that, it also can make the students did not think again about what is their mistake.

The Reasons Why the Teacher does Those Types of Feedback on Students' Writing

The use of written feedback on writing required to improve students' skills and students' knowledge. The teacher suggested for other teacher to use written feedback on their learning process so the students' writing can be better on the next day. Written feedback can make the students aware and understand about the mistake that they made on their writing.

From the interviewed, it can be found that the teacher used direct feedback. The reason was that the students can more easily understand the mistakes, from the feedback, it will make them better on their next writing and it also can make them have more vocabularies and they can fix the mistakes more easily.

The Students' Response to the Teacher's Written Feedback on Students' Writing

The students' interview was done to get more detail information about students' response to the teachers' written feedback. There were four students 
interviewed to got the data. The list of interview questions can be seen on appendix C.

From the interviewed, it can be found that the students felt happy when their teacher gave written feedback on their writing. The students preferred direct feedback because they did not have to think more about the correct words. After the students received the written feedback, some students usually read their teacher's written feedback carefully, understand what was needed, re- read what they have written, and then make changes in light of their teachers' comments. If they did not know about the correction, they will ask their teacher about it.

\section{Discussions}

Harmer (2007) said that there were two types of feedback. there were direct feedback and indirect feedback, but Park had a different view, there were there types of written feedback. There were: form-focused feedback, content based feedback and also integrated feedback. In this research, it was used Harmer's theory which was direct feedback and indirect feedback.

From the research findings, it can be found that the use of the direct written feedback is discovered more than indirect written feedback. There were 59 direct feedback found from 15 students' writing. It can be seen that the teacher directly correct the students' writing by giving mark and the correct word.

Indirect written feedback was a kind of written feedback indicates the error by giving mark on it. It was divided into two categories: coded and un-coded indirect written feedback. In this study, there were 55 un-coded indirect feedbacks 
from 15 students' writing and there were no coded indirect feedback because the teacher did not know about coded indirect feedback.

Based on the research findings, the teacher used both of written feedback by Harmer (2007). The teacher used direct feedback and also indirect feedback. but the teacher mostly used direct feedback on students' writing. In indirect feedback, the teacher did not used coded indirect feedback because the teacher did not know about the codes. The teacher made direct feedback with giving the circle and crossed the wrong word on students' mistake.

Based on teacher's interview, it can be found that the teacher mostly used direct feedback. The reason was because by giving direct feedback on students' writing, the teacher want to the students more understand about the mistake and did not want to make the students confuse about the correct words and also their writing will be better because they learn from the mistakes. In this case, it also found that the teacher has limited time to correct all of the mistakes. So, when the teacher has limited time, the teacher only circled the error.

From the interviewed above, it can be found that the students felt happy when their teacher gave written feedback on their writing. The students preferred direct feedback because they did not have to think more about the correct words. After the students received the written feedback, some students usually read their teacher's written feedback carefully, understand what is needed, re- read what they have written, and then make changes in light of their teachers' comments. 


\section{Conclusions and Suggestions}

\section{Conclusions}

The aims of this study was to find out the types of teacher's written feedback in writing that given by the teacher for grade 10 in SMA YAPIM Taruna Sei Rotan and to find out the reasons of using the feedback and also to find out the students' response to the teacher's written feedback.

1. There were two differences of feedback, namely direct written feedback and indirect written feedback. Indirect written feedback was included coded indirect feedback and un-coded indirect feedback. In direct written feedback, there were 59 feedbacks with $52 \%$ from 15 students' writing. Meanwhile, there were 55 un-coded indirect feedbacks with $48 \%$ from 15 students' writing.

From the data, it can be found that the teacher used direct written feedback and indirect written feedback, but the teacher mostly used direct written feedback because the teacher made the correct word above the wrong word. The teacher used direct feedback because it will be easier to the students understand about the correct word and did not think more about which one is correct and also they will be better on their next writing.

2. From the teacher's interview, it can be found that the reasons why the teacher of SMA YAPIM Taruna Sei Rotan using direct written feedback because the students will know about their mistake easily and their writing will be better because they learn from the mistakes. 
3. In students' interview, it can be found that the students felt happy when their teacher gave a correction to their writing. The students said that direct feedback was more effective than indirect feedback because when their teacher only gave a circle, they felt confuse about what is the correct word. Moreover, most of students mention that they read all of the written feedback that has given by the teacher to know which one was wrong or which one was right from their written. If they did not know about the correction, they will ask their teacher about it.

\section{Suggestions}

Considering the conclusions above, some suggestions are presented in this part. As discussed in chapter I, this study hopefully can give advantageous information both theoretically and practically.

1. For teacher

a. The teacher is expected to provide a clear description of feedback on writing, especially how students perceive and interpret the feedback given.

b. The teacher is expected to improve their techniques in giving feedback, so that the objectives of the English teaching program especially in writing can be achieved.

2. For researchers

In this research only focused on types of teacher's written feedback that was used by English teacher, the reasons of using those types of feedback. Therefore, it was suggested that other researchers can develop a relevant research that can conduct this study. 


\section{REFERENCES}

Arikunto, S. (2006). Prosedur Penelitian Suatu Pendekatan Praktik $\left(5^{\text {th }}\right.$ Ed).Jakarta: Rineka Cipta.

Ary, D., Jacobs, L. C., Razavieh, A., \& Sorensen, C. (2006). Introduction to research in education. (7th ed.). Wadsworth: Cengage Learning.

Bitchener, J., Young, S. \& Cameron, D. (2005). The Effect of Different Types of Corrective Feedback on ESL Student Writing. Journal of Second Language Writing. Vol. 14. 191-205.

Bryne, D. (2007). Teaching Writing Skill. London: Longman Group Ltd.

Carvalho, C., Martins, D., Santana, L., \& Feliciano, L. (2014). Teacher Feedback: Educational Guidance in Different School Contexts. Procedia Journal Social and Behavioral Sciences. 159. $219-223$.

Doughlas, B. (2001). Teaching by Principle. San Fransisco state University : Longman.

Eggen, P., \& Kauchak, D. (2010). Educational Psychology. London: Pearson Education.

Elashri, I. I. E. A.F (2013). The Impact of the Direct Teacher Feedback Strategy on EFL Secondary Stage Students' Writing Performance. Ph. D, Dissertation. Mansoura: Mansoura University.

Ellis, R. (2009). A Typology of Written Corrective Feedback Types. ELT Journal. 63(20),97-107.

Ferris, D. (2002). Treatment of Error in Second-Language Student Writing. Ann Arbour: University of Michigan.

Ferris, D. (2004). The "Grammar Correction" Debate in L2 Writing: Where are, and where do we go from here? (and what do we do in the mean time ... ?). Journal of Second Language Writing.Vol.13. 49-62.

Harmer, Jeremy. (2001).The Practise of English Language Teaching. London : Longman.

Hayland, Ken. (2002).Teaching and Researching. London : Longman.

Jamalinesari, A. Et, al (2015). The Effect of Teacher-Written Direct vs. Indirect Feedback on Students' Writing. Procedia Journal - Social and Behavioral Sciences. 192. $116-123$. 
Knapp, P., \&Watkins, M. (2005). Genre, Text, Grammar. Sydney: Univeristy of New South Wales Press.

Lewis, Marylin.(2002). Giving Feedback in Language Classes. The University ofAuckland : SEAMO Regional Language Centre.

Liu, Yingliang. (2008). The Effects of Error Feedback in Second Language Writing.Arizona Working Papers in SLA \& Teaching, Vol. 15. 65-79.

Maleki, A., \& Eslami, E., (2013). The Effects of Written Corrective Feedback Techniques on EFL Students' Control Over Grammatical Construction of Their Written English. Theory and Practice in Language Studies. Vol. 3. $1250-1257$.

Panhoon, S., \& Wongwanich, S. (2014). An Analysis of Teacher Feedback for Improving Teaching Quality in Primary Schools. Procedia - Social and Behavioral Sciences. 116. $4124-4130$.

Ruminingsih. (2002). Students' Response to Teacher Written Feedback on their Composition. Thesis. Yogyakarta: Department of Language and Arts Education, Faculty of Teacher Training and Education, Sanata Dharma University Yogyakarta.

Srichanyon, N. (2012). Teacher Written Feedback for L2 Learners' Writing Development. Silpakorn University Journal of Social Sciences, Humanities and Arts. Vol. 12(1). 7 - 17.

Tootkaboni, A., \& Khatib, M. (2014). The Efficacy of Various Kinds of Error Feedback on Improving Writing Accuracy of EFL learners. Bellatera Journal of Teaching \& Learning Language \& Literature. Vol. 7(3). 30 46.

Truscott, J. (1996). The Case Against Grammar Correction in L2 Writing Classes. Language Learning. 46. 327-369. 